\title{
Staphylococcus aureus and Streptococcus agalactiae: prevalence, resistance to antimicrobials, and their relationship with the milk quality of dairy cattle herds in Minas Gerais state, Brazil ${ }^{1}$
}

\author{
Alan A. Mesquita ${ }^{2}$ (D) Christiane M.B.M. Rocha ${ }^{3}$, Fabio R.P. Bruhn ${ }^{4}$, \\ Dircéia A.C. Custódio ${ }^{3}$, Mirian S. Braz ${ }^{3}$, Sandra M. Pinto ${ }^{5}$, Délcio B. Silva ${ }^{6}$ \\ and Geraldo M. Costa ${ }^{3 *}$
}

\begin{abstract}
Mesquita A.A., Rocha C.M.B.M., Bruhn F.R.P., Custódio D.A.C., Braz M.S., Pinto S.M., Silva D.B. \& Costa G.M. 2019. Staphylococcus aureus and Streptococcus agalactiae: prevalence, resistance to antimicrobials, and their relationship with the milk quality of dairy cattle herds in Minas Gerais state, Brazil. Pesquisa Veterinária Brasileira 39(5):308-316. Departamento de Medicina Veterinária, Universidade Federal de Lavras, Campus Universitário, Cx. Postal 3037, Lavras, MG 37200-000, Brazil. E-mail: marciocostavet@gmail.com

Bovine mastitis is the most frequent disease worldwide in dairy herds, causing high economic losses to producers and industry, as well as having implications for public health due to the zoonotic potential of some agents involved in its etiology and the increased risk of antimicrobial residues in milk and its derivatives. Considering the multifactorial aspect of this disease, knowledge of the agents involved in its etiology and their antimicrobial susceptibility profiles is very important. This study was conducted with 306 dairy herds from the Campo das Vertentes region, located in the south of Minas Gerais state, whose owners were milk suppliers to a dairy in the same region. The study involved approximately 34,000 dairy cows and covered an area of approximately $12,564 \mathrm{~km}^{2}$. In these herds, prevalence rates of Staphylococcus aureus and Streptococcus agalactiae and their relationship with bulk milk somatic cell counts (BMSCC), total bacterial counts (TBC), and daily production were evaluated. In addition, analyses of resistance of these pathogens to the antimicrobials most commonly used in the treatment of mastitis in dairy herds were performed. Microbiological analyses of milk samples from collect from bulk milk tanks were performed aiming to evaluate the prevalence of $S$. aureus and S. agalactiae. For these proposes, the modified Baird-Parker Agar medium was used for detection of S. aureus and the modified Edwards Agar medium, enriched with 5\% defibrinated sheep blood, was used for detection of $S$. agalactiae. The disc diffusion technique was applied to evaluate antimicrobial resistance. Results show high prevalence rates of S. aureus (70.3\%) and S. agalactiae $(67.0 \%)$ in the dairy farms studied, with $47.71 \%$ of the herds showing both pathogens. Associations between BMSCC and the presence of pathogens $S$. aureus and S. agalactiae and between TBC and the presence of $S$. agalactiae were observed, demonstrating the influence of these pathogens in milk quality. No variation was observed in the distribution of $S$. aureus and $S$. agalactiae in the different strata of daily production. High levels of resistance and multi-resistance were observed among the pathogens $S$. aureus
\end{abstract}

\footnotetext{
${ }^{1}$ Received on November 22, 2018.

Accepted for publication on December 9, 2018.

2 Departamento de Zootecnia, Universidade Federal de Lavras (UFLA), Campus Universitário, Cx. Postal 3037, Lavras, MG 37200-000, Brazil.

${ }^{3}$ Departamento de Medicina Veterinária, Universidade Federal de Lavras (UFLA), Campus Universitário, Cx. Postal 3037, Lavras, MG 37200-000. *Corresponding author: marciocostavet@gmail.com
}

\footnotetext{
${ }^{4}$ Faculdade de Veterinária, Universidade Federal de Pelotas (UFPel), Cx. Postal 354, Campus Universitário, Capão Leão, RS 96010-900, Brazil.

${ }^{5}$ Departamento de Ciências dos Alimentos, Universidade Federal de Lavras (UFLA), Campus Universitário, Cx. Postal 3037, Lavras, MG 37200-000.

${ }^{6}$ Departamento de Medicina Veterinária, Instituto Federal de Educação, Ciência e Tecnologia do Sul de Minas, Campus Muzambinho, Estrada de Muzambinho, Morro Preto, Muzambinho, MG 37890-000, Brazil.
} 
and S. agalactiae. The results indicate the need for more effective control measures for mastitis caused by S. aureus and S. agalactiae in the dairy herds of the region studied and more judicious use of antimicrobials in order to reduce the problem of resistance to them.

INDEX TERMS: Staphylococcus aureus, Streptococcus agalactiae, mastitis, antimicrobial resistance, milk quality, dairy herds, Minas Gerais, Brazil, cattle, bacterial diseases, bacterioses, pathology.

\section{RESUMO.- [Staphylococcus aureus e Streptococcus agalactiae: prevalência, resistência aos antimicrobianos e suas relações com a qualidade do leite em rebanhos leiteiros} de Minas Gerais, Brasil.] A mastite bovina é a doença de maior frequência em rebanhos leiteiros em nível mundial, acarretando grandes prejuízos econômicos aos produtores e à indústria. Além disso, esta enfermidade tem implicações na saúde pública, devido ao potencial zoonótico de alguns agentes envolvidos em sua etiologia e por aumentar os riscos de resíduos de antimicrobianos no leite e derivados. Considerando o aspecto multifatorial da mastite bovina, o conhecimento dos agentes envolvidos em sua etiologia e os perfis de suscetibilidade aos antibióticos é de suma importância. 0 estudo envolveu 306 fazendas de leite da região de Campo das Vertentes, localizada no sul de Minas Gerais, cujos proprietários eram fornecedores de leite para um laticínio da região, totalizando aproximadamente 34.000 animais e abrangendo uma área aproximada $12.564 \mathrm{~km}^{2}$. Nestes rebanhos, avaliaram-se a prevalência de Staphylococcus aureus e Streptococcus agalactiae e a relação destes agentes com os índices de contagem de células somáticas do leite do tanque de expansão (CCSt), contagem bacteriana total (CBT) e produção diária. Analisou-se também a resistência destes patógenos aos antimicrobianos mais comumente utilizados no tratamento da mastite em rebanhos leiteiros. Análises microbiológicas de amostras de leite dos tanques de expansão foram realizadas para se determinar as prevalências dos patógenos S. aureus e S. agalactiae. Para a detecção de S. aureus, utilizou-se o meio seletivo Ágar Baird-Parker modificado e para a detecção de S. agalactiae, o meio seletivo Ágar Edwards modificado, enriquecido com $5 \%$ de sangue ovino desfibrinado. Foi utilizada a técnica de difusão em discos para a avaliação de resistência aos antimicrobianos. Os resultados apontaram altas prevalências de $S$. aureus $(70,3 \%)$ e de $S$. agalactiae $(67,0 \%)$, com $47,71 \%$ dos rebanhos examinados apresentando ambos os agentes. Verificaram-se associações entre a CCSt e a presença dos patógenos $S$. aureus e $S$. agalactiae, e também entre a CBT e a presença de $S$. agalactiae, demonstrando a interferência negativa destes patógenos nestes quesitos de qualidade. Não se observaram variações nas distribuições dos patógenos $S$. aureus e nem $S$. agalactiae em função da produção diária das propriedades estudadas. Níveis elevados de resistência e de multirresistência foram observados para ambos os agentes. Os resultados apontam a necessidade de medidas mais efetivas de controle para S. aureus e S. agalactiae nos rebanhos da região estudada e do uso mais criterioso dos antimicrobianos, visando minimizar o problema da resistência aos mesmos.

TERMOS DE INDEXAÇãO: Staphylococcus aureus, Streptococcus agalactiae, mastite, resistência a antimicrobianos, qualidade do leite, rebanhos leiteiros, Minas Gerais, Brasil, bovinos, bacterioses, patologia.

\section{INTRODUCTION}

Bovine mastitis is considered the main disease in dairy cattle farming worldwide (Lopes et al. 2012, Ruegg 2012, Costa et al. 2013). It is an infectious process usually caused by the presence of pathogenic microorganisms in the mammary gland, affecting the production and composition of quarter milk, with reflexes mainly in somatic cell counts (SCC), total bacterial counts (TBC), and contents of casein and fat (Freitas et al. 2005, Santos \& Fonseca 2007, Langoni et al. 2017). Bovine mastitis can also cause economic losses owing to expenses with veterinary medicines and services and, in some cases, to death or early discard of affected animals (Oviedo-Boyso et al. 2007, Lopes et al. 2011, 2012). In addition, agents involved in its etiology, which in many cases are multi-resistant, may pose a risk to public health because of their involvement in food poisoning, and these microorganisms may carry resistance genes that can be horizontally transferred to bacteria in the human microbiota (De Vliegher et al. 2012, Forsythe 2013).

Bovine mastitis can be caused by different agents, including bacteria, viruses, fungi, and algae (Ranjan et al. 2006, Reyher et al. 2012). Among the bacteria, Staphylococcus aureus and Streptococcus agalactiae are the most frequently isolated pathogens in intramammary infections in Brazilian cattle. Previous studies have reported that $S$. agalactiae was found in $60 \%$ of the rural properties in the Zona da Mata region in Minas Gerais state (Brito et al. 1999) and in 39.7\% of the farms in different municipalities of this state (Elias et al. 2012). Oliveira et al. (2013) studied the etiology of mastitis in approximately 6,000 lactating dairy cows from 112 herds of farms located in the states of Minas Gerais and Rio de Janeiro, and they found prevalence of $S$. aureus and S. agalactiae in $93.0 \%$ and $41.0 \%$ of the herds assessed, respectively. Cunha et al. (2015), in a study conducted in the municipality of Viçosa, in the Zona da Mata region of Minas Gerais state, observed prevalence of subclinical mastitis of $55.4 \%$ in the in the dairy herds evaluated, with Corynebacterium sp. (32.99\%), S. aureus (28.35\%), and S. agalactiae $(13.66 \%)$ as the most frequent pathogens.

Combating bovine mastitis presents a high demand for the use of antibiotics, which are administered mainly for the treatment of clinical cases and in the dry cow therapy (Erskine et al. 2004); however, when antibiotic therapy is conducted indiscriminately, it becomes a determining factor for the selection of resistant strains. Antimicrobial resistance associated with indiscriminate use of antibiotics and management failures are the major obstacles to the success of antibiotic therapy in combating mastitis (Medeiros 2015); this combination can disseminate resistant strains in the environment and cause serious public health problems (Santos et al. 2006, OIE 2010). Therefore, it is important to emphasize that these medicines should be used more judiciously and antibiogram tests should be performed to choose the most appropriate drugs for the treatment and 
prevention of bovine mastitis (Diniz et al. 2010, Jain et al. 2012, Costa et al. 2013).

Considering the economic relevance of bovine mastitis and its implications on human and animal health, it is essential to monitor the agents most commonly involved in its etiology, as well as the resistance indices of these pathogens to the antimicrobials used to combat them, thus enabling monitoring of their resistance dynamics and adoption of more effective therapeutic protocols for their control. In this context, the present study aimed to evaluate the prevalence rates of Staphylococcus aureus and Streptococcus agalactiae in dairy herds from Campo das Vertentes region, located in the south of Minas Gerais state, whose owners were milk suppliers to a dairy in the same region, and their relationship with bulk milk somatic cell counts (BMSCC), total bacterial counts (TBC), and daily production, as well as evaluate the resistance of these pathogens to the antimicrobials most commonly used in the treatment of mastitis in dairy cattle.

\section{MATERIALS AND METHODS}

This study was conducted with 306 dairy herds from the Campo das Vertentes region, located in the south of Minas Gerais state, involving approximately 34,000 dairy cows and covering an area of approximately $12,564 \mathrm{~km}^{2}$ (FAEMG 2006). The owners of these herds were milk suppliers to a dairy in the region and expressed an interest in participating in the study. Thus, study sampling for choosing the participating properties was conducted for convenience, and the inclusion criteria comprised the previous relationship of the owners with the dairy and the research unit.

A non-probabilistic, descriptive study was conducted to determine the prevalence rates of pathogens Staphylococcus aureus and Streptococcus agalactiae in all properties linked to dairy (306). To this end, milk samples of approximately $40 \mathrm{~mL}$ were aseptically collected from the expansion tanks after homogenization by trained technicians of the dairy and they were stored in sterile vials at $-20^{\circ} \mathrm{C}$ until analysis. Milk samples were collected directly from the bulk milk tanks of the farms, with a small time variation ( $<30$ days).

For detection of $S$. aureus, a $50 \mu \mathrm{L}$ aliquot of each milk sample was cultured on Petri plates containing modified Baird-Parker Agar selective medium and incubated at $37^{\circ} \mathrm{C}$ for $24-48 \mathrm{~h}$. The samples that, after incubation, showed $1-5 \mathrm{~mm}$ diameter, black colonies with glossy appearance, convex shape, and formation of two halos in their contour, indicating lipolytic and proteolytic activity, were considered positive for S. aureus (Siqueira 1995). For isolation of S. agalactiae, a $50 \mu \mathrm{L}$ aliquot of each milk sample was cultured on Petri plates containing modified Edwards Agar selective medium enriched with 5\% defibrinated sheep blood. Samples that showed growth of 1-2mm diameter, bluish colonies with bright appearance and convex shape, with or without formation of opaque zone at their contour were considered positive. All dishes were incubated at $37^{\circ} \mathrm{C}$ for $24-48 \mathrm{~h}$. All cultures were performed in duplicate. From the cultures that tested positive, five colonies suggestive of each of the agents of interest (S. aureus and S. agalactiae) were randomly selected and submitted to confirmatory tests according to the National Mastitis Council (NMC 2004). After phenotypic characterization, the isolates were stored in Brain-heart infusion (BHI) broth containing glycerol $(15 \% \mathrm{v} / \mathrm{v})$ at $-20^{\circ} \mathrm{C}$ until performance of the other assays.

The disc diffusion technique was applied to evaluate in vitro antimicrobial resistance according to the specifications of the Clinical and Laboratory Standards Institute (CLSI 2013). To this end, we used three isolates of $S$. aureus from 99 different properties randomly selected among those that tested positive for this bacterium and three isolates of $S$. agalactiae from 93 different farms randomly selected among those that tested positive to this bacterium. The three isolates of each agent from each farm were used to compose a pool that was used to perform the antimicrobial susceptibility tests. The following antimicrobials were tested: ampicillin, cephalothin, cefoperazone, ceftiofur, enrofloxacin, florfenicol, gentamicin, lincomycin, neomycin, nitrofurantoin, novobiocin, polymyxin B, penicillin $\mathrm{G}$, oxacillin, sulfamethoxazole-trimethoprim, tetracycline, streptomycin and ciprofloxacin. Isolates of S. aureus (ATCC-25923) and Escherichia coli (ATCC 25992) were used as control in the antibiogram tests. Based on the standards previously defined by the CLSI (2013), isolates were classified as susceptible, moderately susceptible, or resistant. Isolates classified as moderately susceptible were considered resistant for statistical calculations. The multiple antibiotic resistance (MAR) index was calculated from these results. The index MAR was determined by the percentage ratio between the number of antimicrobials for which the isolate tested resistant and the total number of antimicrobials tested. MAR $\geq 0.2$ characterizes multi-resistance according to Krumperman (1983).

Data on total bacterial counts (TBC) and bulk milk somatic cell counts (BMSCC) were obtained at the dairy from the biweekly evaluations conducted in laboratories of the Brazilian Milk Quality Network (RBQL). Results of the five most recent TBC and BMSCC analyses of each property were used to obtain the arithmetic means of these factors, from which the existence of association with the microbiological data (presence/absence of pathogens S. aureus and S. agalactiae) of the farms was assessed.

Aiming to identify whether the presence of pathogens $S$. aureus and S. agalactiae was associated with the daily production of the farms and the impact of these agents on the TBC and BMSCC indices of the properties, we assessed the existence of a correlation between presence of pathogens $S$. aureus and S. agalactiae in different strata of daily milk production ( $\leq 100 \mathrm{~L} /$ day; $>100$ and $\leq 500 \mathrm{~L} /$ day; $>500$ and $\leq 1000 \mathrm{~L} /$ day; $\geq 1000 \mathrm{~L} /$ day), as well as in different mean scores of BMSCC $(\leq 200 \mathrm{cell} / \mathrm{mL} ;>200$ and $\leq 500 \mathrm{cell} / \mathrm{mL}$; $>500$ and $\leq 1,000 \mathrm{cell} / \mathrm{mL} ;>1,000 \mathrm{cell} / \mathrm{mL}$ ) and TBC $(\leq 10 \mathrm{CFU} / \mathrm{mL}$; $>10$ and $\leq 50 \mathrm{CFU} / \mathrm{mL} ;>50$ and $\leq 100 \mathrm{CFU} / \mathrm{mL} ;>100 \mathrm{CFU} / \mathrm{mL}$ ).

Statistical analyses were processed using the Statistical Package for the Social Sciences (SPSS, Chicago, USA) software, version 20.0 for Windows ${ }^{\circledR}$. Correlations between the presence/absence of agents S. aureus and S.agalactiae and the BMSCC and TBC indices and the daily milk production of the farms were assessed using the Pearson's chi-squared test $\left(X^{2}\right)$ at 5.0\% significance level. Since application of the Kolmogorov-Smirnov test showed that data distribution was not normal, the non-parametric Mann-Whitney test was used to verify the existence of difference in the distribution of the quantitative variables (daily milk production, BMSCC, and TBC) and between the qualitative variables (presence of $S$. aureus and S. agalactiae).

\section{RESULTS AND DISCUSSION}

Results of this study showed high prevalence rates of pathogens Staphylococcus aureus $(70.3 \%)$ and Streptococcus agalactiae $(67.0 \%)$ among the assessed dairy herds (306), with $47.71 \%$ showing presence of both agents, $89.54 \%$ showing presence of at least one agent, and only $10.45 \%$ farms showing absence of both agents (Table 1). These results corroborate the findings of previous studies in the literature. Brito et al. (1999) verified prevalence rates of $77.80 \%$ for $S$. aureus and $60 \%$ for S. agalactiae when analyzing 6,315 milk samples from 48 dairy herds in the regions of Zona da Mata and Campo das 
Vertentes in Minas Gerais state. Arcuri et al. (2006) evaluated the microbiological quality of milk in 24 cattle herds in the southeast of Minas Gerais state and north of Rio de Janeiro state and observed prevalence rates of $91.66 \%$ for $S$. aureus and $50 \%$ for S. agalactiae. In a study conducted with 112 dairy herds in the states of Minas Gerais and Rio de Janeiro involving approximately 6.000 dairy cows, Oliveira et al. (2013) found prevalence rates of $93.0 \%$ and $41.0 \%$ for $S$. aureus and S. agalactiae, respectively.

The high prevalence rates observed in the present survey for pathogens $S$. aureus and $S$. agalactiae (Table 1) suggest that the control measures for infectious mastitis are not being correctly applied, a finding that corroborates the results reported by Rodrigues et al. (2017). This fact emphasizes the need to adopt specific measures for the control of these contagious pathogens that affect the daily production of herds and the milk quality, especially the BMSCC index.

Analyses of the BMSCC and TBC indices as a function of the daily milk production of the properties are presented in Tables 2 and 3. The legislation actual in Brazil - Normative
Instruction no. 07 (Brasil 2016) - establishes a limit up to $400,000 \mathrm{cell} / \mathrm{mL}$ for BMSCC. However, BMSCC scores $>200,000 \mathrm{cell} / \mathrm{mL}$ are indicative of losses in milk production and quality, indicating subclinical mastitis at high levels in the herd (Barbosa et al. 2002, Coldebella et al. 2004, Magalhães et al. 2006).

Findings of the present study showed that $50 \%$ of the herds presented BMSCC $\geq 400,000$ cell $/ \mathrm{mL}$, with mean of $483,000 \mathrm{cell} / \mathrm{mL}$. These results are in agreement with those reported by Rodrigues et al. (2017), who verified a geometric annual BMSCC mean in herds in southeastern Brazil of $518,000 \mathrm{cell} / \mathrm{mL}$, with a confidence interval from 491,000 to $546,000 \mathrm{cell} / \mathrm{mL}$; these results are similar to those found in the present study - 483,000 cell/mL. High levels of BMSCC can cause numerous losses to the dairy industry, because they directly affect the composition of milk and, consequently, reduce its shelf life and that of its derivatives (Silva \& Nogueira 2010).

The results presented in Table 4 show that, among the farms with lower BMSCC scores, the prevalence rates of

Table 1. Prevalence of pathogens Staphylococcus aureus and Streptococcus agalactiae in the bulk milk tanks of dairy herds in the region of Campo das Vertentes/MG, 2017

\begin{tabular}{|c|c|c|c|c|}
\hline Factor & Unit & Values & $\%$ & $\mathrm{CI}$ \\
\hline \multirow[t]{2}{*}{ S. aureus } & Present & 215 & 70.3 & \\
\hline & Absent & 91 & 29.7 & $(24.9-35.1)$ \\
\hline S. agalactiae & Present & 205 & 67.0 & \\
\hline Presence of both agents & Present & 146 & 47.71 & \\
\hline Absence of both agents & Absent & 32 & 10.45 & \\
\hline
\end{tabular}

Table 2. Bulk milk somatic cell counts (BMSCC) of dairy herds in the region of Campo das Vertentes/MG, 2017

\begin{tabular}{|c|c|c|c|c|c|}
\hline \multirow{2}{*}{ Daily production } & \multicolumn{4}{|c|}{ BMSCC x 1,000 (cell/mL) } & \multirow{2}{*}{ Herd tota } \\
\hline & $\leq 200$ & $201-500$ & $501-1.000$ & $\geq 1.000$ & \\
\hline$\leq 100$ & $10(16.67 \%)$ & $33(55.00 \%)$ & $12(20.00 \%)$ & $5(8.33 \%)$ & 60 \\
\hline $100-500$ & $18(11.11 \%)$ & $81(50.00 \%)$ & $55(33.95 \%)$ & $8(4.94 \%)$ & 162 \\
\hline $500-1000$ & $3(6.98 \%)$ & $28(65.12 \%)$ & $8(18.60 \%)$ & $4(9.30 \%)$ & 43 \\
\hline$\geq 1000$ & $3(7.32 \%)$ & $22(53.66 \%)$ & $13(31.71 \%)$ & $3(7.32 \%)$ & 41 \\
\hline Total & $34(11.11 \%)$ & $164(53.59 \%)$ & $88(28.76 \%)$ & $20(6.54 \%)$ & 306 \\
\hline
\end{tabular}

Table 3. Total bacterial counts (TBC) in bulk milk tanks of dairy herds in the region of Campo das Vertentes/MG, 2017

\begin{tabular}{|c|c|c|c|c|c|}
\hline \multirow{2}{*}{ Daily production } & \multicolumn{4}{|c|}{ TBC $\times 1,000(\mathrm{CFU} / \mathrm{mL})$} & \multirow{2}{*}{ Herd total } \\
\hline & $\leq 10$ & $11-50$ & $51-100$ & $\geq 101$ & \\
\hline$\leq 100$ & $18(30.00 \%)$ & $29(48.33 \%)$ & $7(11.29 \%)$ & $6(9.68 \%)$ & 60 \\
\hline $100-500$ & $45(27.77 \%)$ & $86(53.08 \%)$ & 17 (10.56\%) & $14(8.70 \%)$ & 162 \\
\hline $500-1000$ & $14(32.56 \%)$ & $24(55.81 \%)$ & $3(6.98 \%)$ & $2(4.65 \%)$ & 43 \\
\hline$\geq 1000$ & $11(27.50 \%)$ & $23(56.09 \%)$ & $5(12.50 \%)$ & $2(5.00 \%)$ & 41 \\
\hline Total & 89 (29.08\%) & $161(52.61 \%)$ & $32(10.46 \%)$ & $24(7.84 \%)$ & 306 \\
\hline
\end{tabular}

Table 4. Prevalence of pathogens Staphylococcus aureus and Streptococcus agalactiae as a function of bulk milk somatic cell counts (BMSCC) of dairy herds in the region of Campo das Vertentes/MG, 2017

\begin{tabular}{|c|c|c|c|c|c|}
\hline \multirow{2}{*}{ Variable } & \multicolumn{4}{|c|}{ BMSCC x 1,000 (cell/mL) } & \multirow{2}{*}{ Total } \\
\hline & $\leq 200$ & $201-500$ & $501-1000$ & $>1000$ & \\
\hline Presence of $S$. aureus & $19(55.88 \%)$ & $114(69.51 \%)$ & $66(75.00 \%)$ & $17(85.00 \%)$ & $216(70.30 \%)$ \\
\hline Presence of S. agalactiae & $15(44.12 \%)$ & $112(68.29 \%)$ & $65(73.86 \%)$ & $13(65.00 \%)$ & $205(66.99 \%)$ \\
\hline Presence of both agents & $8(23.53 \%)$ & $76(46.34 \%)$ & $50(56.82 \%)$ & $12(60.00 \%)$ & $146(47.71 \%)$ \\
\hline Absence of both agents & $8(23.53 \%)$ & $15(9.15 \%)$ & $7(7.95 \%)$ & $2(10.00 \%)$ & $32(10.46 \%)$ \\
\hline
\end{tabular}


pathogens $S$. aureus and S. agalactiae are generally lower, and it can be observed that $23.53 \%$ of the properties with BMSCC $<200,000 \mathrm{cell} / \mathrm{mL}$ showed absence of both agents, whereas only $10 \%$ of the farms with BMSCC $>1,000,000$ cell $/ \mathrm{mL}$ had the same result. In the latter, the prevalence rates verified for pathogens S. aureus and S. agalactiae were $85 \%$ and $65 \%$, respectively.

The BMSCC indices obtained in the present study suggest that improvements need to be made in the control of mastitis, especially regarding contagious pathogens, because the BMSCC scores observed in most properties are above those accepted in the international market, especially in the European Union, where the limit is $<400.000$ cell $/ \mathrm{mL}$, but with a decreasing trend in the coming years, since the national BMSCC scores in the Scandinavian countries ranged from 200,000 to $250,000 \mathrm{cell} / \mathrm{mL}$ (More 2009).

Current legislation (Brasil 2016) establishes a TBC limit of $100,000 \mathrm{CFU} / \mathrm{mL}$ for milk from bulk milk tanks. Among the properties assessed in the present study, $92.16 \%$ showed $\mathrm{TBC} \leq 100,000 \mathrm{CFU} / \mathrm{mL}$, with only $7.84 \%$ of them presenting scores $>100,000 \mathrm{CFU} / \mathrm{mL}$. Increased TBC indices can be caused by failures in the washing of the utensils that come in contact with the milk (milking machine and expansion tank), and faults in cleaning and antisepsis of udder prior to milking and in post-milking cooling, as well as by the presence of intramammary infection, especially when infected with streptococci that cause subclinical mastitis (Santos \& Fonseca 2007, Vargas et al. 2013). This fact may explain the increased TBC indices found in the herds affected by the S. agalactiae pathogen, as it can be verified in Table 5. Such finding corroborates the study by Zadoks et al. (2004), who reported increased TBC of milk from bulk milk tanks in dairy herds affected by $S$. agalactiae.

Prevalence of $S$. aureus was greater than that of $S$. agalactiae in all daily production strata, except for the 500-1,000 L/day stratum, in which a lower prevalence rate was observed for S. aureus $(60.47 \%)$, with a prevalence rate of $S$. agalactiae of $67.44 \%$ (Table 6). The smallest prevalence rate for S. agalactiae was found in the daily production stratum of $>1,000 \mathrm{~L} /$ day; however, no significant difference was verified with respect to any of the daily milk production strata $(p>0.05)$. Also, no significant correlation was observed between the pathogens $S$. aureus and $S$. agalactiae $(p=0.601)$, that is, they may be present in the herds regardless of each other.

No significant correlation was found between daily milk production and presence of pathogens $(S$. aureus and $S$. agalactiae) $(p>0.05)$, which shows that they are equally distributed among the herds, regardless of the production stratum (Table 7). No association was verified between daily production and TBC $(p>0.05)$ and between daily production and BMSCC ( $p>0.05)$, demonstrating that the daily production of the properties did not influence these variables (Table 7).

Table 5. Prevalence of pathogens Staphylococcus aureus and Streptococcus agalactiae in the different mean scores of total bacterial counts (TBC) in bulk milk tanks of dairy herds in the region of Campo das Vertentes/MG, 2017

\begin{tabular}{|c|c|c|c|c|c|}
\hline \multirow{2}{*}{ Variable } & \multicolumn{4}{|c|}{$\mathrm{TBC} \times 1,000(\mathrm{CFU} / \mathrm{mL})$} & \multirow{2}{*}{ Total } \\
\hline & $\leq 10$ & $11-50$ & $51-100$ & $\geq 101$ & \\
\hline Presence of $S$. aureus & $59(66.29 \%)$ & $120(75.00 \%)$ & $22(40.00 \%)$ & $15(62.50 \%)$ & $215(70.59 \%)$ \\
\hline Presence of $S$. agalactiae & $51(57.30 \%)$ & $111(69.38 \%)$ & $26(47.27 \%)$ & $17(70.83 \%)$ & $205(66.99 \%)$ \\
\hline Presence of both agents & $34(38.20 \%)$ & $85(53.13 \%)$ & $33(60.00 \%)$ & $21(87.50 \%)$ & $173(56.54 \%)$ \\
\hline Absence of both agents & $13(14.61 \%)$ & $15(9.38 \%)$ & $2(3.64 \%)$ & $2(8.33 \%)$ & $32(10.46 \%)$ \\
\hline
\end{tabular}

Table 6. Variation in the prevalence rates of Staphylococcus aureus and Streptococcus agalactiae and inadequacies in bulk milk somatic cell counts (BMSCC) and total bacterial counts (TBC), as a function of daily production, in bulk milk tanks of dairy herds in the region of Campo das Vertentes/MG, 2017

\begin{tabular}{|c|c|c|c|c|c|}
\hline Daily production (L) & $\mathrm{N}(\%)$ & $\begin{array}{c}\text { Presence of } S \text {. aureus } \\
\mathrm{N}(\%)\end{array}$ & $\begin{array}{c}\text { Presence of } S \text {. } \\
\text { agalactiae } \mathrm{N}(\%)\end{array}$ & $\begin{array}{c}\text { BMSCC }>500,000 \text { cell } / \mathrm{mL} \\
\mathrm{N}(\%)\end{array}$ & $\begin{array}{c}\mathrm{TBC}>100,000 \mathrm{CFU} / \mathrm{mL} \\
\mathrm{N}(\%)\end{array}$ \\
\hline$\leq 100$ & $62(20.26 \%)$ & $46(73.02 \%)$ & $43(68.25 \%)$ & $19(30.16 \%)$ & $1(1.59 \%)$ \\
\hline $100-500$ & $163(52.94 \%)$ & $115(70.55 \%)$ & $111(68.10 \%)$ & $64(53.27 \%)$ & $5(1.63 \%)$ \\
\hline $500-1000$ & $42(14.05 \%)$ & $26(60.47 \%)$ & $29(67.44 \%)$ & $12(27.91 \%)$ & $1(2.33 \%)$ \\
\hline$>1000$ & $39(12.75 \%)$ & $28(71.79 \%)$ & $22(56.41 \%)$ & $14(35.90 \%)$ & $1(2.56 \%)$ \\
\hline All farms & $306(100 \%)$ & $215(70.30 \%)$ & $205(67.00 \%)$ & $109(35.62 \%)$ & $8(2.61 \%)$ \\
\hline
\end{tabular}

Table 7. Correlation between quantitative variables: daily production, bulk milk somatic cell counts (BMSCC), and total bacterial counts (TBC) of dairy herds in the region of Campo das Vertentes/MG that tested positive for Staphylococcus aureus and Streptococcus agalactiae in 2017

\begin{tabular}{|c|c|c|c|c|c|c|}
\hline \multirow{2}{*}{ Variable } & \multicolumn{2}{|c|}{ S. aureus } & \multirow{2}{*}{$p$ value } & \multicolumn{2}{|c|}{ S. agalactiae } & \multirow{2}{*}{$p$ value } \\
\hline & Positive & Negative & & Positive & Negative & \\
\hline Prevalence N (\%) & 215 (70.3) & $91(29.7)$ & & $205(67.0)$ & $101(33.00)$ & \\
\hline Average daily production (L) & 467 & 528 & 0.223 & 460 & 538 & 0.216 \\
\hline Mean BMSCC (cell/mL) & 503,000 & 434,000 & $0.003^{*}$ & 503,000 & 442,000 & $0.002^{*}$ \\
\hline Mean TBC (CFU/mL) & 40,000 & 38,0000 & 0.867 & 46,000 & 38,000 & $0.009 *$ \\
\hline
\end{tabular}

*Significant by the Mann-Whitney test at 5\%. 
Significant associations were observed between BMSCC and presence of $S$. aureus ( $p=0.003), \mathrm{BMSCC}$ and presence of $S$. agalactiae $(p=0.002)$, and TBC and presence of $S$. agalactiae $(p=0.009)$ in the dairy herds investigated, which suggests that the presence of these agents in the herds negatively influence the BMSCC and that the presence of S. agalactiae is associated with increased TBC. In this study, herds affected by $S$. agalactiae showed mean TBC of $46,000 \mathrm{CFU} / \mathrm{mL}$, whereas herds affected by $S$. aureus presented mean TBC of $40,000 \mathrm{CFU} / \mathrm{mL}$ (Table 7). Table 5 evidences that the properties with TBC $>100,000 \mathrm{CFU} / \mathrm{mL}$ had higher levels of infection caused by S. aureus and S. agalactiae (87.50\%), whereas presence of both agents was observed in only $38.20 \%$ of the farms with $\mathrm{TBC}<10,000 \mathrm{CFU} / \mathrm{mL}$. These results corroborate the findings by Lopes Júnior et al. (2012), who verified correlation between BMSCC, TBC, and mastitis pathogens, and found correlation between BMSCC and TBC greater than 0.60 for the agents assessed, in which the coefficient of linear regressions for S. agalactiae (0.542) was higher compared with those for the other mastitis pathogens, followed by that of $S$. aureus (0.503), suggesting that the intensity of the inflammatory process measured by the BMSCC was associated with the bacterial burden present in the milk of animals affected by mastitis.
Tables 8 and 9 show the results of the antimicrobial susceptibility tests for pathogens $S$. aureus and S. agalactiae. It can be observed that the resistance indices of S. aureus varied from $2 \%$ to $72 \%$, with the following most efficient drugs and percentages of susceptible isolates: sulfamethoxazole-trimethoprim (98\%), florfenicol (97\%), nitrofurantoin (94\%), and ciprofloxacin (91\%). The highest resistance levels were observed for polimixin B (72\%), penicillin G (69\%), ampicillin (60\%), streptomycin (58\%), and tetracycline (49\%) (Table 8). The Multiple Antibiotic Resistance (MAR) indices for S. aureus ranged from 0.00 to 0.84 - mean of 0.33 , with $62,6 \%$ of the isolates presenting multi-resistance (Table 9).

The antimicrobial susceptibility profiles verified for $S$. aureus in the present study are in agreement with the findings of previous surveys. Cardoso et al. (2000) isolated and subjected to antibiogram tests 127 strains of $S$. aureus in 23 municipalities in Minas Gerais state from 1994 to 1997. The most effective in vitro antimicrobials were cefotaxime (100\%), enrofloxacin (98.4\%), gentamycin (98.4\%), rifampicin (96.1\%), chloramphenicol (90.4\%), sulfamethoxazole-trimethoprim (86.6\%), and novobiocin (85.8\%). The following medicines showed the highest resistance levels: polimixin B (8.7\%), ampicillin (28.6\%), and penicillin G (29.1\%).

Table 8. Results of antimicrobial susceptibility tests on strains of Staphylococcus aureus and Streptococcus agalactiae isolated from milk bulk tanks of dairy herds in the region of Campo das Vertentes/MG, 2017

\begin{tabular}{|c|c|c|c|c|c|c|}
\hline \multirow[b]{2}{*}{ Antibiotic } & \multicolumn{3}{|c|}{ Staphylococcus aureus } & \multicolumn{3}{|c|}{ Streptococcus agalactiae } \\
\hline & $\begin{array}{c}\mathrm{N} \text { of resistant } \\
\text { strains }\end{array}$ & $\begin{array}{l}\% \text { of resistant } \\
\text { strains }\end{array}$ & $\begin{array}{c}\text { CI 95\% } \\
\text { (Lower limit - } \\
\text { Upper limit) } \\
\end{array}$ & $\begin{array}{l}\mathrm{N} \text { of resistant } \\
\text { strains }\end{array}$ & $\begin{array}{c}\% \text { of resistant } \\
\text { strains }\end{array}$ & $\begin{array}{c}\text { CI 95\% } \\
\text { (lower limit - } \\
\text { upper limit) } \\
\end{array}$ \\
\hline Ampicillin & 59 & 60 & $(49.8-68.7)$ & 34 & 37 & $(27.5-46.7)$ \\
\hline Cephalothin & 24 & 24 & $(16.9-33.5)$ & 62 & 67 & $(56.6-75.4)$ \\
\hline Cefoperazone & 28 & 28 & $(20.4-37.8)$ & 79 & 85 & $(76.3-90.8)$ \\
\hline Cefotaxime & 35 & 35 & $(26.6-45.2)$ & 82 & 88 & $(80.1-93.3)$ \\
\hline Ceftiofur & 25 & 25 & $(17.7-34.6)$ & 73 & 78 & $(69.1-85.6)$ \\
\hline Ciprofloxacin & 9 & 9 & $(4.9-16.4)$ & 23 & 25 & $(17.1-34.4)$ \\
\hline Chloramphenicol & 5 & 5 & $(2.2-11.3)$ & 41 & 44 & $(34.4-54.2)$ \\
\hline Enrofloxacin & 17 & 17 & $(11.0-25.8)$ & 44 & 47 & $(37.5-57.4)$ \\
\hline Streptomycin & 57 & 58 & $(47.7-66.3)$ & 89 & 96 & $(89.5-98.3)$ \\
\hline Florfenicol & 3 & 3 & $(1.0-8.5)$ & 1 & 1 & $(0.0-4.0)$ \\
\hline Gentamicin & 21 & 21 & $(14.3-30.3)$ & 47 & 51 & $(40.6-60.5)$ \\
\hline Lincomycin & 34 & 34 & $(25.7-44.1)$ & 88 & 95 & $(88.0-97.3)$ \\
\hline Neomycin & 31 & 31 & $(23.0-41.0)$ & 76 & 82 & $(72.6-88.3)$ \\
\hline Nitrofurantoin & 6 & 6 & $(2.8-12.6)$ & 22 & 24 & $(16.2-33.2)$ \\
\hline Novobiocin & 45 & 45 & $(36.0-55.3)$ & 90 & 97 & $(96.0-100)$ \\
\hline Oxacillin & 38 & 38 & $(29.4-48.2)$ & 90 & 97 & $(90.9-98.9)$ \\
\hline Penicillin G & 68 & 69 & $(57.9-76.1)$ & 80 & 86 & $(77.5-91.7)$ \\
\hline Polymyxin B & 71 & 72 & $(62.2-79.7)$ & 89 & 96 & $(89.5-98.3)$ \\
\hline sulfamethoxazole-trimethoprim & 2 & 2 & $(0.6-7.1)$ & 14 & 15 & $(9.2-23.7)$ \\
\hline Tetracycline & 49 & 49 & $(39.9-59.2)$ & 72 & 77 & $(67.9-84.7)$ \\
\hline
\end{tabular}

Table 9. Cumulative frequency of resistance to antimicrobials of Staphylococcus aureus and Streptococcus agalactiae isolated from bulk milk tanks of dairy herds in the region of Campo das Vertentes/MG, 2017

\begin{tabular}{|c|c|c|c|c|c|}
\hline \multirow{2}{*}{ Pathogen } & \multicolumn{5}{|c|}{ Number of antimicrobials cumulatively tested } \\
\hline & 0 & 1 & 2 & 3 & $>4^{*}$ \\
\hline S. aureus & 7 & 7 & 15 & 8 & 62 \\
\hline S. agalactiae & 0 & 0 & 2 & 0 & 91 \\
\hline
\end{tabular}

*Resistance to four or more antimicrobials characterizes multi-resistance in this study. 
Donatele et al. (2002) analyzed antimicrobial susceptibility in 180 strains of $S$. aureus isolated from subclinical mastitis in herds in Rio de Janeiro state and found high resistance rates for $\beta$ - lactam antibiotics (82.9\%) and tetracyclines (24.4\%), with the highest susceptibility indices obtained for sulfamethoxazole-trimethoprim and gentamicin. Coelho et al. (2007) reported high rates of resistance to penicillin (67.7\%) and ampicillin (64.4\%) for S. aureus; however, differently from the findings of the present research, gentamicin was more effective against the tested isolates, with only $12.5 \%$ resistance. Nunes et al. (2007) evaluated antimicrobial resistance in 234 pathogens isolated from cases of mastitis in dairy properties in Portugal and observed high levels of resistance to penicillin (78.7\%) and ampicillin (65.6\%) in $S$. aureus isolates; results similar to those found in the present study. Costa et al. (2013), assessed the antimicrobial resistance profile in $352 \mathrm{~S}$. aureus isolates in 35 dairy herds in the south of Minas Gerais state and observed that the polymyxin B presented the highest resistance index (82\%), followed by the $\beta$-lactam antibiotics ampicillin and penicillin, which showed resistance indices of 80.92 and $80.45 \%$, respectively. The same authors also found multi-resistance with MAR index, varying from 0.2 to 0.5 , differently from what was verified in the present survey, which showed MAR values ranging from 0.00 to 0.76 .

Results in disagreement with those of our study were also reported by Freitas et al. (2005), who verified resistance indices $>50 \%$ for gentamicin, lincomycin, tetracycline, and oxacillin in $S$. aureus isolates in dairy herds in Pernambuco state, and by Fontana et al. (2010), who evaluated the resistance of $S$. aureus isolates of 174 dairy cows in nine different farms in the municipality of Jataí, Goiás state, and observed 100\% resistance to oxacillin, penicillin and ampicillin - indices higher than those found in the present study.

Antimicrobial susceptibility tests for the $S$. agalactiae demonstrated that the overall resistance of the isolates varied from $1 \%$ to $97 \%$. The most efficient in vitro medicines with their respective percentages of susceptible isolates are shown ahead: florfenicol (99\%), sulfamethoxazole-trimethoprim (85\%), nitrofurantoin (76\%), ciprofloxacin (75\%), and ampicillin (63\%). The antimicrobials that showed the highest resistance rates were novobiocin (97\%), oxacillin (97\%), polimixin B (96\%), streptomycin (96\%), and lincomycin (95\%) (Table 8). Among the isolates of S. agalactiae, $97.8 \%$ of strains showed multi-resistance, with MAR indices varying from 0.11 to 0.95 , and mean of 0.65 (Table 9).

Silva etal. (2017) analyzed the antimicrobial susceptibility profiles of $S$. agalactiae isolates in cattle herds in different Brazilian regions. Their study showed the following drug resistance rates: erythromycin (26.23\%), tetracycline (47.54\%), gentamycin (3.28\%), sulfonamide (98.36\%), and clindamycin (29.51\%). All isolates assessed were susceptible to penicillin, ceftiofur, and cephalothin. The results of the aforementioned survey differed from those of the present research especially with respect to penicillin and gentamicin resistance rates, which were lower than those observed herein, with values of $86 \%$ and $51 \%$, respectively. Jain et al. (2012) assessed the antimicrobial resistance profiles in $S$. agalactiae isolates from cases of subclinical mastitis and observed resistance indices, in general, lower than those obtained in the present study. Our results show higher overall indices of resistance and multi-resistance for $S$. agalactiae compared with $S$. aureus in the farms investigated. Table 9 shows that $48.48 \%$ of the $S$. aureus isolates were resistant to five or more different antimicrobials, whereas this index was 95.70\% for S. agalactiae isolates. According to Nunes et al. (2007) and Fontana et al. (2010), poorly directed antibiotic therapy and indiscriminate use of antimicrobials, resulting in increased selective pressure on resistant strains, contribute to increased antimicrobial resistance rates. Different authors have referred to the difficulty in treating intramammary infections caused by $S$. aureus, with low cure rates (Costa et al. 2012, 2013, Silva et al. 2014). This fact is justified not only by the resistance phenomenon, but also by its escape mechanisms of the immune system and of the antimicrobials in the infected gland, such as intracellular invasion and biofilm formation (Novick et al. 2001, DeLeo et al. 2009).

As for intramammary infections caused by $S$. agalactiae, increasing difficulty has been observed with regards to treatment, including failure of the classic blitz therapy protocols, which in part may be associated with the high resistance rates observed in the present study. The differences between the results of the susceptibility tests verified in this research for pathogens S. aureus and S. agalactiae and those of previous studies in the literature can be justified by spatial and temporal variations in the origin of the isolates, as well as by the different methodologies used in the antibiotic susceptibility tests (minimal inhibitory concentration (MIC); disc diffusion). Differences in the origin of the isolates (whether from clinical or subclinical mastitis, if from individual mammary quarters or expansion tanks, or from the environment) and in selection pressure due to the selective and/or indiscriminate use of antimicrobials may also justify this variation in the resistance indices.

Results of the present study demonstrated high resistance levels among $S$. aureus and S. agalactiae isolates for the main medicines used in the treatment of mastitis, which highlights the need for constant monitoring of susceptibility profiles with a view to a more careful selection of antimicrobials in order to improve high cure rates and minimize the increase in drug resistance. In addition, it is fundamental to periodically and permanently monitor the pathogens involved in the etiology of bovine mastitis and their resistance indices, because these parameters are very dynamic and present spatial and temporal variations. According to Myllys et al. (1994), resistance to antimicrobials is an important factor in the establishment and dissemination of bacterial clones in a herd, and shows close association with changes in management, such as the use of systematic antibiotic treatment, cattle stabling, and introduction of mechanical milking machines - factors that impose selective pressure on the pathogens that cause mastitis.

\section{CONCLUSIONS}

Results show high prevalence rates of pathogens Staphylococcus aureus and Streptococcus agalactiae in dairy farms of the study region and association between presence of these agents in the herd with total bacterial counts (TBC) and bulk milk somatic cell counts (BMSCC), demonstrating that the presence of these pathogens negatively influence milk quality.

No difference in the presence of pathogens $S$. aureus and $S$. agalactiae were observed as a function of the daily production of the properties, demonstrating homogeneous distribution of these agents in the herds regardless of the daily production. 
High resistance and multi-resistance levels were observed among the pathogens S. aureus and S. agalactiae, emphasizing the need for more judicious use of antimicrobials used in mastitis control.

Conflict of interest statement. - The authors declare that there are no conflicts of interest.

\section{REFERENCES}

Arcuri E.F., Brito M.A.V.P., Brito J.R.F., Pinto S.M., Ângelo F.F. \& Souza G.N. 2006. Qualidade microbiológica do leite refrigerado nas fazendas. Arq. Bras. Med. Vet. Zootec. 58(3):440-446. <http://dx.doi.org/10.1590/ S0102-09352006000300024>

Barbosa C.P., Benedetti E. \& Ribeiro S.C. 2002. Relação entre CCS e os resultados do CMT no diagnostico de mastite bovina. Biosci. J. 18(1):93-102.

Brasil 2016. Instrução Nomativa no 7, de 3 de maio de 2016. Diário Oficial da União no 84 de 04/05/16, Seção 1, Brasília, DF, p.11.

Brito M.A.V., Brito J.R., Ribeiro M.T. \& Veiga V.M.O. 1999. Padräo de infecção intramamária em rebanhos leiteiros: exame de todos os quartos mamários das vacas em lactação. Arq. Bras. Med. Vet. Zootec. 51(2):129-135. <http:// dx.doi.org/10.1590/S0102-09351999000200001>

Cardoso H.F.T., Costa G.M. \& Silva N. 2000. Susceptibilidade a antibióticos de Staphylococcus aureus isolados de leite bovino no Estado de Minas Gerais. Revta Bras. Med. Vet. 22(5):199-206.

CLSI 2013. Performance Standards for Antimicrobial Susceptibility Testing. 23rd Informational Supplement, CLSI document M100-S23, Wayne, Pennsylvania. 205p.

Coelho S.M.O., Moraes R.A.M., Soares L.C., Pereira I.A., Gomes L.P. \& Souza M.M.S. 2007. Mapeamento do perfil de resistência e detecção do gene mecA em Staphylococcus aureus e Staphylococcus intermedius oxacilina-resistentes isolados de espécies humanas e animais. Ciência Rural 37(1):195-200. <http://dx.doi.org/10.1590/S0103-84782007000100031>

Coldebella A., Machado P.F., Demétrio C.G.B., Ribeiro Júnior P.J., Meyer P.M., Corassin C.H. \& Cassoli L.D. 2004. Contagem de células somáticas e produção de leite em vacas holandesas confinadas. Revta Bras. Zootec. 33(3):623-634. <http://dx.doi.org/10.1590/S1516-35982004000300011>

Costa G.M., Paiva L.V., Figueiredo H.C., Figueira A.R., Pereira U.P. \& Silva N. 2012. Population diversity of Staphylococcus aureus isolated from bovine mastitis in Brazilian dairy herds. Res. Vet. Sci. 93(2):733-735. <http:// dx.doi.org/10.1016/j.rvsc.2011.09.014> <PMid:22035658>

Costa G.M., Barros R.A., Custódio D.A.C., Pereira U.P., Figueiredo D.J. \& Silva N. 2013. Resistência a antibióticos em Staphylococcus aureus isolados de mastite em bovinos leiteiros de Minas Gerais, Brasil. Arqs Inst. Biológico, São Paulo 80(3):297-302.

Cunha A.F., Bragaça L.J., Quintao L.C., Coelho K.S., Souza F.N. \& Cerqueira M.M.O.P. 2015. Prevalence, etiology and risk factors of subclinical mastitis in dairy cattle of Viçosa-MG. Acta Vet. Bras. 9(2):48-54.

De Vliegher S., Fox L.K., Piepers S., McDougall S. \& Barkema H.W. 2012. Invited review: mastitis in dairy heifers: nature of the disease, potential impact, prevention, and control. J. Dairy Sci. 95(3):1025-1040. <http:// dx.doi.org/10.3168/jds.2010-4074> <PMid:22365187>

DeLeo F.R., Chambers H.F. \& Chambers H.F. 2009. Reemergence of antibioticresistant. J. Clin. Invest. 119(9):2464-2474. <http://dx.doi.org/10.1172/ JCI38226> <PMid:19729844>

Diniz C.M., Melo R.T., Mendonça E.P., Coelho L.R., Fonseca B.B. \& Rossi D.A. 2010. Resistência a oxacilina em Staphylococcus spp. isolado de leite mastítico. Revta Inst. Adolfo Lutz 69(4):482-488.

Donatele D.M., Motta O.V. \& Folly M.M. 2002. Perfil antimicrobiano de linhagens de Staphylococcus spp. coagulase positiva na mastite subclínica de vacas leiteiras nas regiões norte e noroeste do estado do Rio de Janeiro. Revta Napgama 5(2):3-6.
Elias A.O., Cortez A., Brandão P.E., Silva R.C. \& Langoni H. 2012. Molecular detection of streptococcus agalactiae in bovine raw milk samples obtained directly from bulk tanks. Res. Vet. Sci. 93(1):34-38. <http://dx.doi. org/10.1016/j.rvsc.2011.07.016> <PMid:21862092>

Erskine R., Cullor J., Schaellibaum M., Yancey B. \& Zecconi A. 2004. Bovine mastitis pathogens and trends in resistance to antibacterial drugs. NMC Annual Meeting Proceedings, p.1-15.

FAEMG 2006. Diagnóstico da Pecuária Leiteira do Estado de Minas Gerais em 2005: relatório de pesquisa. Federação de Agricultura do Estado de Minas Gerais, Belo Horizonte. 156p.

Fontana V.L.D.S., Almeida M.J.S.M.G., Leite C.Q.F., Mirta E.T., Fusco A.M., Fontana S.C.A.P., Souza C.M. \& Eurides A. 2010. Etiologia da mastite bovina subclínica, sensibilidade dos agentes às drogas antimicrobianas e detecção do gene da $\beta$ - lactamase em Staphylococcus aureus. Vet. Zootec. 17(4):568-576.

Forsythe S.J. 2013. Microbiologia da Segurança dos Alimentos. $2^{2}$ ed. Artmed, Nebrasca. 602p.

Freitas M.F.L., Pinheiro Júnior J.W., Stamford T.L.M., Rabelo S.S.A., Silva D.R., Silveira Filho V.M., Santos F.G.B., Sena M.J. \& Mota R.A. 2005. Perfil de sensibilidade antimicrobiana in vitro de Staphylococcus. Arqs Inst. Biológico, São Paulo 72:171-177.

Jain B., Tewari A., Bhandari B.B. \& Jhala M.K. 2012. Antibiotic resistance and virulence genes in Streptococcus agalactiae isolated from cases of bovine subclinical mastitis. Vet. Arch. 82(5):423-432.

Krumperman P.H. 1983. Multiple antibiotic resistance indexing of Escherichia coli to identify high-risk sources of fecal contamination of foods. Appl. Environ. Microbiol. 46(1):165-170.<PMid:6351743>

Langoni H., Salina A., Oliveira G.C., Junqueira N.B., Menozzi B.D. \& Joaquim S.F. 2017. Considerações sobre o tratamento das mastites. Pesq. Vet. Bras. 37(11):1261-1269.<http://dx.doi.org/10.1590/s0100-736x2017001100011>

Lopes Júnior J.E.F., Lange C.C., Brito M.A.V.P., Santos F.R., Silva M.A.S., Moraes L.C.D. \& Souza G.N. 2012. Relationship between total bacteria counts \& somatic cell counts from mammary quarters infected by mastitis pathogens. Ciência Rural 42(4):691-696. <http://dx.doi.org/10.1590/ S0103-84782012000400019>

Lopes M.A., Demeu F.A. \& Franco Neto A. 2012. Avaliação do impacto econômico da mastite. Arqs Inst. Biológico, São Paulo 79:477-483.

Lopes M.A., Demeu F.A., Abreu L.R. \& Franco Neto A. 2011. Influência da contagem de células somáticas sobre o impacto economico da mastite em rebanhos bovinos leiteiros. Arqs Inst. Biológico, São Paulo 78(4):493-499.

Magalhães H.R., El Faro L., Cardoso V.L., Paz C.C.P., Cassoli L.D. \& Machado P.F. 2006. Influência de fatores de ambiente sobre a contagem de células somáticas e sua relação com perdas na produção de leite de vacas da raça holandesa. Revta Bras. Zootec. 35(2):415-421.<http://dx.doi.org/10.1590/ S1516-35982006000200011>

Medeiros M. 2015. Agentes causadores de mastite e resistência bacteriana. Revta Cient. Med. Vet. 2(1):45-60.

More S.J. 2009. Global trends in milk quality : implications for the irish dairy industry. Ir. Vet. J. 62(Suppl.4):5-14. <http://dx.doi.org/10.1186/20460481-62-S4-S5><PMid:22081986>

Myllys V., Honkanen-Buzalski T., Huovinen P., Sandholm M. \& Nurmi E. 1994. Association af changes in the bacterial ecology of bovine mastitis with changes in the use of milking machines \& antibacterial drugs. Acta Vet. Scand. 35(4):363-369. <PMid:7676918>

NMC 2004. Microbiological procedures for the diagnosis of bovine udder infection and determination of milk quality. 4 th ed. Verona, Wisconsin, p.46.

Novick R.P., Schlievert P. \& Ruzin A. 2001. Pathogenicity and resistance Islands of Staphylococci. Microbes Infect. 3(7):585-594. <http://dx.doi. org/10.1016/S1286-4579(01)01414-9><PMid:11418332> 
Nunes S.F., Cavaco L.M. \& Vilela C.L. 2007. Antimicrobial susceptibility traits of subclinical bovine mastitis pathogens in Portugal. Revta Port. Ciênc. Vet. 102(563/564):275-280.

OIE 2010. Risk Assessment for antimicrobial resistance arising from the use of antimicrobials in animals. Terrestrial Animal Health Code, World Organization for Animal Health, Paris, p.1-6.

Oliveira E.F., Brito M.A.V., Lange C.C., Mendonça L.C. \& Meurer I.R. 2013. Prevalência de patógenos contagiosos em rebanhos da associação dos criadores de gado holandês do Estado de Minas Gerais, 2011-2012. Vet. Zootec. 20(1):265-268.

Oviedo-Boyso J., Valdez-Alarcón J.J., Cajero-Juárez M., Ochoa-Zarzosa A., LópezMeza J.E., Bravo-Patiño A. \& Baizabal-Aguirre V.M. 2007. Innate immune response of bovine mammary gland to pathogenic bacteria responsible for mastitis. J. Infect. 54(4):399-409. <http://dx.doi.org/10.1016/j. jinf.2006.06.010><PMid:16882453>

Ranjan R., Swarup D., Patra R.C. \& Nandi D. 2006. Bovine protothecal mastitis: a review. CAB Rev., Perspectives Agricult., Vet. Sci. Nutr. Nat. Resources 1(17):1-7.

Reyher K.K., Haine D., Dohoo I.R. \& Revie C.W. 2012. Examining the effect of intramammary infections with minor mastitis pathogens on the acquisition of new intramammary infections with major mastitis pathogens, a systematic review and meta-analysis. J. Dairy Sci. 95(11):6483-6502. <http://dx.doi. org/10.3168/jds.2012-5594><PMid:22981582>

Rodrigues L.G., Aquino M.H.C., Silva M.R., Mendonça L.C., Mendonça J.F.M., Souza G.N. \& Rodrigues L.G. 2017. A time series analysis of bulk tank somatic cell counts of dairy herds located in Brazil and the United States. Ciência Rural 47(4):1-6. <http://dx.doi.org/10.1590/0103-8478cr20160618>
Ruegg P.L. 2012. New perspectives in udder health management. Vet. Clin. N. Am., Food Anim. Pract. 28(2):149-163. <http://dx.doi.org/10.1016/j. cvfa.2012.03.001><PMid:22664200>

Santos C.D.M., Leal G.A. \& Rossi D.A. 2006. Frequência e suscetibilidade a antibióticos de Staphylococcus spp. isolados de leite de vacas com mastites recorrentes de rebanhos da região de Uberlândia-MG. Vet. Notícias 12(2):83-88

Santos M.V. \& Fonseca L.F.L. 2007. Estratégias para Controle de Mastite e Melhoria da Qualidade do Leite. Manole, São Paulo, p.215-314.

Silva J.R., Castro G.A.C., Gonçalves S.M., Custódio D.A.P., Mian G.F. \& Costa G.M. 2017. In vitro antimicrobial susceptibility and genetic resistance determinants of Streptococcus agalactiae isolated from mastitic cows in Brazilian dairy herds. Semina, Ciênc. Agrárias 38:2581-2594.

Silva M.V.M. \& Nogueira J.L. 2010. Mastite: controle e profilaxia no rebanho bovino. Revta Cient. Eletrôn. Med. Vet. 3(15):9-13.

Silva N., Cardoso H.T.F. \& Costa G.M. 2014. Infecções estafilocócicas na glândula mamária de bovinos. Vet. Zootec. 23:20-35.

Siqueira R.S. 1995. Manual de Microbiologia de Alimentos. Centro Nacional de Pesquisa de Tecnologia Agroindustrial de Alimentos, Embrapa, Rio de Janeiro, p.110-159.

Vargas D.P., Nörnberg J.L., Mello R.O., Sheibler R.B., Milani M.P. \& Mello F.C.B. 2013. Correlações entre contagem bacteriana total e parâmetros de qualidade do leite. Revta Bras. Ciênc. Vet. 20(4):241-247.

Zadoks R.N., Gonzalez R.N., Boor K.J. \& Schukken Y.H. 2004. Mastitis-causing streptococci are important contributors to bacterial counts in raw bulk tank milk. J. Food Prot. 67(12):2644-2650. <http://dx.doi.org/10.4315/0362028X-67.12.2644> <PMid:15633665> 